\title{
HUBUNGAN KOMUNIKASI TERAPEUTIK PERAWAT DENGAN TINGKAT KEPUASAN PASIEN DI RST TK. II KARTIKA HUSADA
}

\author{
Nurse's Therapeutic Communication Relationship With A Level of Patient \\ Satisfaction At RST TK. II Kartika Husada \\ Risky Amelia Aprianti*, Yoga Pramana**, Mita** \\ * Mahasiswi Prodi Keperawatan,Fakultas Kedokteran, Universitas Tanjungpura, \\ Pontianak \\ ** Dosen Keperawatan, Fakultas Kedokteran, Universitas Tanjungpura, Pontianak \\ Jl. Prof. Dr. H. Hadari Nawawi, Pontianak \\ Email: riskyamelia.untan@gmail.com
}

\begin{abstract}
ABSTRAK
Latar Belakang : Komunikasi yang dilakukan oleh perawat berfungsi untuk mendengarkan keluhan pasien serta dapat menjelaskan prosedur tindakan keperawatan yang direncanakan. Perawat dituntut untuk bisa berkomunikasi secara baik kepada pasien. Apabila tidak diterapkan akan mengganggu hubungan terapeutik yang akan berdampak pada ketidakpuasan pasien.

Tujuan : Untuk mengetahui hubungan komunikasi terapeutik perawat dengan tingkat kepuasan pasien di RST TK. II Kartika Husada

Metode : Penelitian kuantitatif dengan menggunakan pendekatan cross sectional. Intrumen yang digunkanan kuisioner komunikasi terapeutik dan kuesioner kepuasan pasien. Sampel dalam penelitian ini menggunakan non probability sampling dengan metode purposive sampling. Jumlah responden 89 orang. Uji statistik yang digunakan adalah Chi-Squere dengan alternatif KolmogorovSmirnov

Hasil : Berdasarkan data dan hasil analisis dengan uji Kolmogorov-Smirnov diperoleh $p$ value $=0,000(\mathrm{p}<0,05)$, yang berarti ada hubungan bermakna antara komunikasi terapeutik dengan tingkat kepuasan pasien.

Kesimpulan : Terdapat hubungan komunikasi terapeutik perawat dengan kepuasan pasien yang menunjukkan bahwa semakin baik komunikasi perawat maka semakin meningkatkan kepuasan pasien. Hal ini yang diperlukan untuk menjadi perawat yang professional demi meningkatkan derajat kesehatan pasien.
\end{abstract}

Kata Kunci : Komunikasi Terapeutik, Kepuasan Pasien

Referensi : 31 (2007-2019) 


\begin{abstract}
Background : Communication made by the nurse serves to listen to patient complaints and can explain the planned nursing action procedures. Nurses are required to be able to communicate well with patients. If not applied, it will interfere with the therapeutic relationship which will have an impact on patient dissatisfaction.

Purpose: Find out "Relations between Nurse Therapeutic Communication and Patient Satisfaction Level in RST TK. II Kartika Husada",

Method: Based on the data and the results of the analysis using the KolmogorovSmirnov test, it was found that $p$ value $=0.000(p<0.05)$, which means that there is a significant relationship between therapeutic communication and the level of patient satisfaction.

Result: Based on the data and the results of the analysis using the KolmogorovSmirnov test, it was found that $p$ value $=0.000(p<0.05)$, which means that there is a significant relations between therapeutic communication and the level of patient satisfaction.

Conclusion: There is a relationship between nurse therapeutic communication and patient satisfaction, which shows that the better the nurse's communication, the more patient satisfaction increases. This is necessary to become a professional nurse in order to improve the patient's health status.
\end{abstract}

Keyword: Therapeutic Communication, Patient Satisfaction

Refference: 31 (2007-2019) 


\section{PENDAHULUAN}

Menurut Depkes RI, 2009 Rumah sakit adalah institusi yang menyelenggarakan pelayanan kesehatan perorangan secara paripurna yang bermutu dan terjangkau dalam mensejahterakan masyarakat yang membutuhkan. Berdasarkan Undang-Undang RI No. 44 tahun 2009 tentang Rumah Sakit yang memiliki fungsi untuk menerapkan pelayanan kesehatan dalam dunia keperawatan baik diluar maupun didalam negeri dan telah diakui oleh pemerintah dibuktikan dengan surat tanda registrasi yang dimiliki. Perawat di Rumah Sakit saat ini ditekankan untuk memiliki STR dan dapat diperpanjang selama 5 tahun sekali. Pelayanan kesehatan sesuai dengan standar kode etik profesi yang telah ditetapkan, karena memilih atau menetapkan prioritas indikator kualitas pelayanan kesehatan sebagai dasar untuk memutuskan tingkat kepuasannya (Siti, M. dkk, 2016).

Kualitas pelayanan kesehatan yang salah satunya dipengaruhi oleh efektivitas komunikasi perawat dan pasien, menurut Agustrianti (2015) Komunikasi efektif seorang perawat ditekankan pada kerjasama dengan pasien. Salah satu alasan keluhan umum pasien di rumah sakit yaitu pasien sering tidak puas dengan kualitas komunikasi dan pelayanan informasi yang diterima dari tenaga kesehatan (Rusnoto, 2019).

Komunikasi terapeutik adalah kemampuan komunikasi yang dimiliki oleh perawat terampil sehingga mempengaruhi pencapaian hasil kesehatan optimal. Komunikasi terapeutik mempengaruhi tingkah laku sehingga menjalin hubungan rasa percaya pada pasien, mencegah terjadinya masalah legal, memberikan kepuasan profesional dalam pelayanan keperawatan dan meningkatkan citra profesi keperawatan serta citra rumah sakit. Komunikasi terapeutik yang sudah dilakukan secara efektif maka dapat dilihat dari tingkat kepuasan yang dimiliki pasien (Handayani, D., \& Armina 2017).

Kepuasaan pasien merupakan suatu tingkat kepuasan yang dialami oleh pasien sebagai akibat dari proses pelayanan kesehatan sesuai dengan apa yang diharapkan pasien. Pasien akan lebih merasa dihargai dan merasa aman dalam berbagi rasa dan pengalaman. Ketidakpuasan pada diri pasien dapat disebabkan oleh beberapa hal yaitu seperti gagal berkomunikasi, krisis waktu, kualitas produk atau jasa, kualitas atau mutu pelayanan, harga, dan biaya (Simanjuntak, 2019).

Berdasarkan penelitian yang dilakukan oleh Putra (2013) menyatakan bahwa ada hubungan komunikasi terapeutik dengan kepuasan pasien di ruang rawat inap RSUDZA serta ada hubungan komunikasi terapeutik pada tahap kerja dengan kepuasan pasien, maka dapat diketahui bahwa ada hubungan komunikasi terapeutik dengan kepuasan pasien di ruang rawat inap kelas III Rumah Sakit Umum Daerah dr. Zainoel Abidin Banda Aceh Tahun 2013.

Hasil studi pendahuluan yang dilaksanakan oleh peneliti di ruang rawat inap di RS TK. II Kartika Husada didapatkan data jumlah perawat sebanyak 182 orang yang berkerja dalam setiap ruangan, jumlah pasien pada tahun 2019 selama tiga bulan terakhir diruang rawat inap sebanyak 2548 pasien, bulan Oktober sebanyak 859 pasien, bulan November sebanyak 857 pasien, bulan Desember sebanyak 832 pasien. Pada wawancara yang dilakukan peneliti bulan Januari 2020 dengan 10 pasien di ruang rawat inap Rumah Sakit TK.II Kartika Husada Pontianak, peneliti menemukan 10 orang pasien mengatakan bahwa sebagian perawat dalam melakukan interaksi komunikasi dengan pasien cukup baik dan pasien juga mengatakan bahwa perawat terkadang hanya sekedar saja dalam berkomunikasi.

Metode pemberian asuhan keperawtan oleh perawat di ruang rawat inap di Rumah Sakit TK.II Kartika Husada Pontianak yaitu metode kasus, satu perawat berkerja menangani beberapa pasien. Hasil wawancara pada pasien yang berada di ruang rawat inap, sebanyak 4 dari 10 pasien mengatakan kualitas pelayanan keperawatan mengenai komunikasi perawat, perhatian perawat, empati perawat, ketanggapan perawat, jaminan pelayanan dan penampilan peawat dikategorikan baik, selebihnya 6 dari 10 pasien mengatakan kemampuan berkomunikasi perawat belum sepenuhnya memperhatikan kepuasan pasien, pasien tidak mengetahui tujuan dari tindakan yang akan dilakukan perawat, namun pasien mengerti bahwa ruang rawat inap merupakan ruangan yang sangat dipenuhi oleh perawatan pasien dengan jumlah perawat yang hanya berkisar 4 atau 5 orang saja untuk setiap pergantian sift.

Peneliti memperoleh data dari Rumah Sakit TK.II Kartika Husada tercatat jumlah 
pasien yang dirawat inap di Rumah Sakit pada periode Desember 2019 dengan BOR 71,63\%. Kelengkapan fasilitas serta banyaknya orang yang berobat, sudah seharusnya Rumah Sakit menjaga mutu dalam bidang pelayanan. Salah satu indikator mutu pelayanan yaitu kepuasan pelanggan atau pasien. Tanpa komunikasi terapeutik, suatu hubungan yang baik antara perawat dan pasien tidak mungkin tercapai. Data mengenai pengukuran tingkat kepuasan yang dimonitoring dari Rumah Sakit Kartika Husada sendiri mencapai $81,45 \%$ secara umum baik dari segi pelayanan, kualitas dan fasilitas yang sudah ada dengan perhitungan melalui sebaran kuesioner kepuasan pasien yang ditentukan oleh SOP rumah sakit tersebut. Mengenai komunikasi yang digunakan perawat dalam mengukur tingkat kepuasan pasien sendiri belum pernah dilakukan penilaian secara khusus dan dari pihak PMKP (perbaikan mutu dan keselamatan pasien) rumah sakit ini juga mengatakan belum ada menerapkan standar komunikasi bagi perawat disetiap ruangan. Berdasarkan dari penjelasan atau latar belakang diatas maka dari itu peneliti tertarik hendak melakukan penelitian tentang hubungan komunikasi terapeutik perawat dengan tingkat kepuasan pasien di Rumah Sakit TK. II Kartika Husada.

\section{METODE}

Desain yang digunakan dalam penelitian ini adalah rancangan cross sectional. Peneliti meneliti hubungan antara variabel independen dan dependen, serta hanya dilakukan satu kali pengamatan selama waktu penelitian (Nursalam, 2017).

Populasi adalah wilayah generelisasi yang terdiri atas obyek/subjek yang mempunyai kuantitas dan karakteristik tertentu yang di tetapkan oleh peneliti (Sugiyono, 2017). Populasi dalam penelitian ini adalah pasien yang berada di Rumah Sakit TK II. Kartika Husada, dengan rata-rata pasien yang dirawat ruang rawat inap dalam 3 bulan terakhir, yaitu bulan Oktober-Desember 2019 sebanyak 849 pasien.

Sampel penelitian yang digunakan adalah pasien yang berada di Rumah Sakit TK II. Kartika Husada memenuhi kriteria inklusi dan kriteria ekslusi. Teknik pengambilan sampel dalam penelitian ini menggunakan non probability sampling, teknik sampling yang digunakan yaitu purposive sampling . Berdasarkan rumus diatas maka besar sampel diruang rawat inap diperoleh sebanyak 89 pasien.

Adapun Kriteria inklusi penelitian ini adalah bersedia menjadi responden penelitian dan mengisi informed consent serta mengisi kuisioner yang peneliti sediakan di googleform, dapat berkomunikasi dengan baik, mampu menulis dan membaca, memiliki handphone dan dapat menggunakannya serta dapat mengakses internet, merupakan pasien yang sedang di rawat Inap di Rumah Sakit TK.II Kartika Husada. Kriteria eklusi dalam peneltian ini adalah pasien yang tidak bersedia menjadi responden peneitian di Rumah sakit TK.II Kartika Husada dan pasien yang belum mendapatkan perawatan selama kurang dari 24 jam.

Instrumen penelitian adalah suatu alat yang digunakan oleh peneliti untuk mengobservasi, mengukur atau menilai suatu fenomena (Dharma, 2017). Instrumen yang digunakan dalam penelitian ini adalah kuesioner dengan metode google form yang berisi checklist tindakan perawat dalam melakukan komunikasi terapeutik dan kepuasan pasien. Menggunakan informed consent, link kuisioner, handphone dan akses internet. Link kuisioner berisi data demografi responden, kuisioner komunikasi terapeutik perawat dan kuesioner kepuasan pasien. Kuesioner komunikasi terapeutik dan kuesioner kepuasan pasien diadaptasi dari peneliti sebelumnya yang sudah melakukan uji validitas dan reliabilitas terdiri dari 10 pertanyaan yang sama yaitu antara jawaban harapan pasien dan jawaban kenyataan pasien. Untuk menentukan komunikasi terapeutik perawat menggunakan penilaian harapan yang diinginkan oleh pasien, sedangkan untuk mengukur kepuasan pasien menggunakan penilaian kenyataan yang diterima pasien. Kuesioner untuk mengetahui Komunikasi Terapeutik dan Kepuasan pasien menggunakan pengukuran skala Guttman yaitu sebanyak 10 pertanyaan.

Pada penelitian ini analisa data pada metode statistik univariat digunakan untuk menganalisa karakteristik dari pasien yaitu: jenis kelamin, usia, pendidikan, pekerjaan, bahasa yang digunakan seharihari dan lama pasien dirawat. Analisis 
bivariat dalam penelitian ini adalah untuk menganalisis hubungan komunikasi terapeutik dengan kepuasan menggunakan uji statistik alternatif kolmogrov-smirnov $(<0,05)$.

\section{HASIL}

Adapun Komunikasi Terapeutik terhadap pelayanan rumah sakit di RST TK. II Kartika Husada dapat dijelaskan pada tabel berikut.

\section{Tabel 4.2 Distribusi Komunikasi} Terapeutik perawat di RST TK. II Kartika Husada

\begin{tabular}{|c|c|}
\hline Komunikasi & $\%$ \\
\hline Kurang & 1,1 \\
\hline Cukup & 12,4 \\
\hline Baik & 86,5 \\
\hline Total & 100,0 \\
\hline \multicolumn{2}{|c|}{ Sumber : Data primer (2020) } \\
\hline \multicolumn{2}{|c|}{$\begin{array}{l}\text { Berdasarkan hasil analisa univariat pada } \\
\text { tabel } 4.2 \text { didapatkan hasil sebanyak } 1(1,1 \%) \\
\text { orang berkomunikasi kurang, sebanyak } 11 \\
(12,4 \%) \text { orang berkomunikasi cukup dan } \\
\text { sebanyak } 77(86,5 \%) \text { orang berkomunikasi } \\
\text { baik. }\end{array}$} \\
\hline \multicolumn{2}{|c|}{$\begin{array}{l}\text { Adapun Kepuasan Pasien terhadap } \\
\text { pelayanan rumah sakit di RST TK. II } \\
\text { Kartika Husada dapat dijelaskan pada } \\
\text { tabel berikut }\end{array}$} \\
\hline Kepuasan & $\mathrm{F} \%$ \\
\hline Kurang & 3.4 \\
\hline Cukup & 19,1 \\
\hline Baik & 77,5 \\
\hline Total & 100,0 \\
\hline
\end{tabular}

Sumber : Data primer (2020)

Berdasarkan hasil analisa table 4.3 didapatkan hasil sebanyak $3(3,4 \%)$ orang dengan tingkat kepuasan kurang, sebanyak 17 $(19,1 \%)$ orang dengan tingkat kepuasan cukup dan sebanyak $69(77,5 \%)$ orang dengan tingkat kepuasan baik.

Adapun nilai harapan dan kenyataan yang terdapat pada dua variabel penelitian di RST TK. II Kartika Husada dapat dijelaskan pada tabel berikut.

Tabel $\quad 4.4$ Distribusi Komunikasi Terapeutik perawat di RST TK. II Kartika Husada

\begin{tabular}{ccc}
\hline $\begin{array}{c}\text { Komun } \\
\text { ikasi } \\
\text { Kepu } \\
\text { asan }\end{array}$ & 0,022 & n Henyataan \\
\hline
\end{tabular}

Berdasarkan hasil analisa tabel 4.4 didapatkan hasil dimana nilai kenyataan lebih besar dari pada nilai harapan, dimana pada tabel tersebut menunjukkan bahwa nilai harapan dalam suatu penelitian yaitu 0,022 yang artinya untuk mengukur bahwa hasil penelitian tersebut sesuai, maka nilai kenyataan harus lebih besar dari nilai harapan penelitian dimana pada tabel tersebut dibuktikan bahwa nilai kenyataan lebih besar dari pada nilai harapan yaitu 0,775 .

Analisis bivariat dalam penelitian ini menjelaskan tentang hubungan komunikasi terapeutik perawat dengan kepuasan pasien di RST TK. II Kartika Husada.

Tabel 4.5 hubungan komunikasi terapeutik perawat dengan kepuasan pasien di RST TK. II Kartika Husada.(n=89)

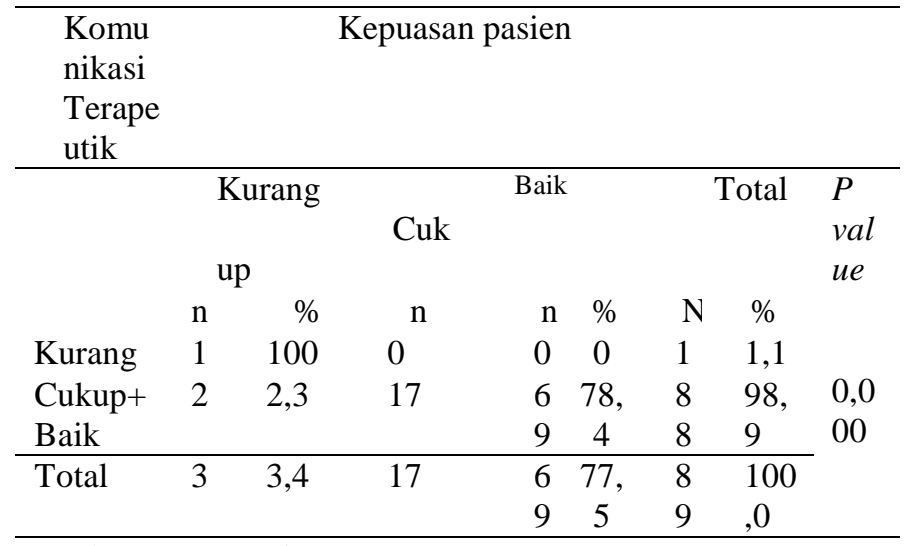

Sumber : Data primer (2020)

Berdasarkan tabel 4.5 didapatkan hasil bahwa responden yang menyatakan Komunikasi terapeutik kurang dengan tingkat kepuasan kurang sebanyak 1 (100\%) orang, komunikasi terapeutik cukup+baik dengan tingkat kepuasan kurang sebanyak 2 (2,3\%), komunikasi terapeutik cukup+baik dengan tingkat kepuasan cukup sebanyak 17 (19,3\%) orang dan komunikasi terapeutik cukup+baik dengan tingkat kepuasan baik sebanyak 69 $(78,4 \%)$ orang.

Berdasarkan data dan hasil analisis dengan uji chi-square diperoleh $p$ value $=$ $0,000 \quad(\mathrm{p}<0,05), \quad$ akan tetapi pada kenyataannya dalam pengambilan keputusan hasil uji chi-square harus memenuhi beberapa kreteria untuk menarik kesimpulan, dimana hasil uji statistik diatas terdapat cell yang 
tidak memenuhi kreteria dikarenakan ada jumlah cell dengan frekuensi harapan (expected count) yang kurang dari 5 lebih dari $20 \%$. Dari data tersebut, peneliti menggambil keputusan untuk melakukan uji statisti kembali dengan kelompok tidak berpasangan dengan melakukan Uji Kolmogorov-Smirnov.

Tabel 4.6 hubungan komunikasi terapeutik perawat dengan kepuasan pasien di RST TK. II Kartika Husada (Uji KolmogorovSmirnov) (n=89).

\begin{tabular}{cccc}
\hline \multicolumn{4}{c}{ Kepuasan+Komunikasi } \\
\cline { 2 - 4 } \cline { 3 - 3 } Kepuasan & 89 & SD & P-Value \\
Komunikasi & 89 & 0,528 & \\
\hline
\end{tabular}

banyaknya keluhan tentang asuhan professional. Perawat harus dapat belajar berkomunikasi secara efektif dengan lebih meningkatkan sikap yang baik, senyum yang ramah, empati yang tinggi dan penuh perhatian. Terbentuknya komunikasi yang baik tentu saja akan memberikan kepuasan pada diri pelanggan atau pasien yang sedang mendapatkan perawatan. Dengan begitu pasien tentu saja akan berminat untuk kembali berkunjung atau berobat ke rumah sakit dan secara tidak langsung citra rumah sakit juga akan semakin meningkat lebih baik. Komunikasi merupakan poin utama selain fasilitas dan pelayanan yang disediakan dari rumah sakit untuk mempertimbangkan derajat mutu perbaikan rumah sakit sebagai tempat
Sumber data primer (2020)

89

Berdasarkan tabel 4.6 didapatkan hasil bahwa responden pada variabel tingkat kepuasan sebanyak $89(100 \%)$ orang dengan standar deviasi 0,528 dan responden pada variabel tingkat komunikasi terapeutik sebanyak $89(100 \%)$ orang dengan standar deviasi 0,501.

Berdasarkan data dan hasil analisis dengan uji Kolmogorov-Smirnov diperoleh $p$ value $=0,000 \quad(\mathrm{p}<0,05)$, yang berarti ada hubungan bermakna antara komunikasi terapeutik dengan tingkat kepuasan pasien.

\section{PEMBAHASAN}

\section{Komunikasi Terapeutik Perawat di RST TK. II Kartika Husada}

Hasil Penelitian yang dilakukan oleh peneliti menunjukan bahwa 89 responden didapatkan hasil sebanyak 1 orang $(1,1 \%)$ mengatakan bahwa komunikasi perawat kurang, sebanyak 11 orang $(12,4 \%)$ menyatakan Komunikasi perawat cukup dan sebanyak 77 orang $(86,5 \%)$ komunikasi perawat baik. Sejalan dengan penelitian yang dilakukan oleh (Febriani, 2015) menunjukan penerapan komunikasi terapeutik perawat dan tingkat kepuasan pasien di ruang rawat inap RSUD Sultan Syarif Mohammad Alkadrie Kota Pontianak sudah baik. Komunikasi terapeutik didapatkan hasil $83,3 \%$ dan kepuasan pasien $81,4 \%$.

Komunikasi yang bersifat buruk merupakan salah satu pendorong dari
0,528 ketersediaan pelayanan kesehatan bagi pasien 0,501 yang membutuhk 90 (9) stutik, 2018).

Kepuasan Pasien di RST TK. II Kartika Husada

Penelitian yang dilakukan menunjukan bahwa dari 89 responden didapatkan hasil sebanyak 3 orang $(3,4 \%)$ menyatakan kurang puas dan sebanyak 17 orang $(19,1 \%)$ menyatakan kurang puas, sedangkan 69 orang $(77,5 \%)$ menyatakan puas. Hal ini sesuai dengan penelitian yang dilakukan Rusnoto (2019) menunjukkan 83,3\% komunikasi baik, $96,7 \%$ pelayanan keperawatan baik dan 95,6\% pasien puas. Menurut Nursalam mengatakan bahwa kepuasan pasien apabila apa yang menjadi kebutuhan, keinginan, harapan pasien, dapat dipenuhi, maka pasien akan puas.

\section{Hubungan Komunikasi Terapeutik Perawat dengan Kepuasan Pasien di RST TK. II Kartika Husada}

Dalam melakukan uji chi-square harus memenuhi beberapa kreteria untuk menarik kesimpulan, pada tabel $3 \times 3$ tidak memenuhi syarat untuk dilakukan uji chi-square sehingga peneliti melakukan penggabungan cell dengan tabel $2 \times 3$ dengan penggabungan pada variabel komunikasi yang awalnya terdapat 3 cell (kurang, cukup dan baik) menjadi 2 cell (kurang dan cukup+baik), setelah itu dimana hasil uji chi-square terdapat cell yang tidak memenuhi kreteria dikarenakan ada jumlah cell dengan frekuensi harapan (expected count) yang kurang dari 5 lebih dari $20 \%$ (Sugiyono 2017). Dari data tersebut, peneliti menggambil keputusan untuk melakukan uji statisti kembali dengan kelompok tidak berpasangan dengan melakukan Uji 
Kolmogorov-Smirnov. Berdasarkan hasil Uji kolmogorov-smirnov didapatkan nilai signifikan yaitu 0,00 $(\mathrm{p}<005)$ artinya terdapat hubungan antara komunikasi terapeutik dengan kepuasan pasien di RST TK. II Kartika Husada.

Menurut Peneliti dari hasil penelitian pasien merasakan puas terhadap komunikasi terapeutik artinya semakin baik komunikasi terapeutik orientasi pasien baru yang diberikan maka pasien akan merasa puas, atau semakin kurang baik komunikasi terapeutik orientasi pasien baru yang diberikan maka pasien akan merasa tidak puas, pasien akan merasa puas apabila kinerja perawat yang diperolehnya sama atau melibihi yang diharapkan dan sebaliknya. Sejalan dengan penelitian yang dilakukan Rusnoto (2019) menunjukkan 83,3\% komunikasi baik, 96,7\% pelayanan keperawatan baik dan 95,6\% pasien puas.

Berdasarkan penelitian yang dilakukan Nita Purnamasari (2019) Hubungan yang dapat terjadi adalah jika pasien mendapatkan komunikasi terapeutik yang baik dengan perawat, maka pasien cenderung akan merasa puas dengan pelayanan yang diberikan oleh perawat. Pasien yang merasa puas dengan pelayanan kesehatan cenderung akan setia lebih lama, kurang sensitif terhadap harga, serta memberi komentar yang baik terhadap pelayanan kesehatan rumah sakit.

Dalam memulai hubungan, tugas utama adalah membina rasa percaya, penerimaan dan pengertian, komunikasi yang terbuka dan perumusan kontak dengan pasien. Diharapkan pasien berperan serta secara penuh dalam kontrak, namun pada kondisi tertentu, maka kontrak dilakukan sepihak dan perawat perlu mengulang kontrak jika kontak realitas pasien meningkat. Salah satu faktor yang dapat mempengaruhi komunikasi adalah lingkungan. Lingkungan interksi akan mempengaruhi komunikasi yang efektif. Suasana yang bising, tidak ada privasi yang tepat akan menimbulkan kerancuan, ketegangan dan ketidaknyaman. Pasien yang puas merupakan aset yang sangat berharga karena apabila pasien puas mereka akan terus melakukan pemakaian terhadap jasa pilihannya. Dalam menciptakan dan mengelola suatu sistem untuk memperoleh pasien yang lebih banyak dan kemampuan untuk mempertahankan pasien, perlu adanya perbaikan atau kesempurnaan kepuasan dengan berbagai strategi pelayanan Rumah Sakit untuk dapat merebut pelanggan (Fahrozy, 2017).

Isymaya dwi 2019 meneliti bahwa sebagian besar responden $64,4 \%$ menyatakan bahwa respon time perawat saat menanggapi keluhan dalam kategori lambat. 64,4\% responden memiliki empati yang baik pada klien, meningkatkan empati perawat pada saat melaksanakan komunikasi terapeutik. empathy care training dapat menjadi alternative pilihan solusi. Penelitian ini juga sejalan dengan penelitian Butar butar dan Fathi tahun 2018, hasil penelitiannya yaitu sebanyak $85,1 \%$ memiliki empati yang baik.

\section{KETERBATASAN PENELITIAN}

Pada saat pelaksanaan penelitian ini secara umum peneliti tidak mengalami kesulitan karena peneliti akan tetapi kondisi covid 19 yang membuat keterbatasan penelitian untuk kontak langsung dan menggali permasalahan belum optimal. Hal ini diatasi peneliti dengan menggunakan asisten dalam penelitian yang bertugas mengumpulkan data langsung ke lapangan. Asisten peneliti sangat terbantu dengan sikap kooperatif dari pasien dan keluarga sehingga proses membina hubungan saling percaya dapat membantu kelancaran penelitian.

\section{IMPLIKASI DALAM KEPERAWATAN}

Penelitian ini dapat menjadi indikator evaluasi dalam pelayanan rumah sakit, khususnya bagi keperawatan terkait pemberian informasi dan juga evaluasi terhadap kepuasan terhadap terhadap komunikasi terapeutik perawat pada pelaksanaan orientai pasien baru, sehingga mutu rumah sakit menjadi lebih meningkat selama memberikan pelayanan keperawatan.

\section{KESIMPULAN DAN SARAN}

Berdasarkan hasil penelitian dan pembahasan hubungan komunikasi terapeutik perawat dengan kepuasan pasien di RST TK. II Kartika Husada maka dapat disimpulkan bahwa karakteristik responden usia responden rata 37,76 (38) tahun, jenis kelamin responden laki-laki sebanyak 45 orang $(50,6 \%)$, pekerjaan responden adalah wiraswasta sebanyak 22 orang $(24,7 \%)$, tingkat pendidikan SMA sebanyak 46 orang $(51,7 \%)$ dan lama dirawat dengan rata 3,87 (4) hari.

Gambaran komunikasi terapetik perawat menunjukan hasil komunikasi kurang sebanyak 1 orang $(1,1 \%)$, komunikasi cukup 
sebanyak 11 orang $(12,4 \%)$ dan komunikasi baik sebanyak 77 orang $(86,5 \%)$. Sedangkan kepuasan pasien selama menjalani perawatan dengan tingkat kepuasan kurang sebanyak 3 orang $(3,4 \%)$, tingkat kepuasan cukup sebanyak 17 orang $(19,1 \%)$ dan tingkat kepuasan baik sebanyak 69 orang $(77,5 \%)$. Sehingga didapatkan bahwa ada Hubungan Komunikasi Terapeutik dengan Kepuasan Pasien di RST Tk. II Kartika Husada dengan nilai signifikan yaitu $0,000(\mathrm{p}<0,05)$

Berdasarkan hasil penelitian dan pembahasan hubungan komunikasi terapeutik perawat dengan kepuasan pasien di RST Tk. II Kartika Husada saran yang ingin disampaikan Bagi Institusi pendidikan hasil penelitian ini dapat menambah kajian baru ilmu pengetahuan dalam bidang kesehatan khususnya dibidang manajemen keperawatan, Bagi Rumah sakit diharapkan dapat melakukan evaluasi dan dapat dijadikan bahan pertimbangan dan data awal sehingga dapat dibuat perencanaan dalam pemberian asuhan keperawatan terutama dalam komunikasi.

Bagi peneliti diharapkan dapat memanfaatkan hasil penelitian yang telah didapat khususnya dalam pengembangan ilmu pengetahuan dan keterampilan terkait menajemen komunikasi terapeutik dan peneliti selanjutnya yang berminat mengadakan penelitian lebih lanjut dengan tema yang sama, sebaiknya peneliti lebih mengarah ke metode pengelompokan pasien dengan membatasi faktor-faktor kepuasan pasien untuk lebih terperinci agar dapat dilakukakan pemetaan secara homogen dalam pengumpulan data.

\section{DAFTAR PUSTAKA}

Agustrianti, P. (2015). Analisis Faktor-Faktor yang Berhubungan dengan Efektivitas Komunikasi Perawat dan Pasien di Ruang Rawat Inap Rumah Sakit Harapan Mulia Kabupaten Bekasi . Jurnal ARSI Vo. 2, No 1.

Ariani, T. A. (2018). Komunikasi Keperawatan. Malang: Universitas Muhammadyah.

From https://books.google.co.id/.

Astutik, A. R. (2018). Komunikasi Terapeutik Dengan Tingkat Kepuasan Pasien di Ruang Melati RSUD Bangil. Program Studi S1 Keperawatan Sekolah Tinggi
Ilmu Kesehatan Insan Cendekia Medika Jombang.

Butarbutar R. dan Fathi A. Gambaran Empati Perawat Dalam Memberikan Asuhan Keperawatan Di Ruang Rawat Inap Rsup H. Adam Malik Medan. Universitas Sumatra Utara: Talenta Publisher. 2018

Dahlan, M. S. (2016). Langkah-Langkah Membuat Proposal Penelitian Bidang Kedokteran dan Kesehatan. Jakarta: CV. Sagung Seto.

Departemen Kesehatan Republik Indonesia. (2009). Pedoman Penyelenggaraan dan Prosedur Rekam Medis Rumah Sakit Di Indonesia Revisi 2. Jakarta: Departemen Kesehatan Republik Indonesia

Dharma, K. K. (2017). Metodologi Penelitian Keperawatan (Pedoman Melaksanakan dan Menerapkan Hasil Penelitian) Edisi Revisi 2015. Jakarta: Trans Info Media.

Dwi Handayani, A. (2017). Faktor-Faktor yang Berhubungan dengan Penerapan Komunikasi Terapeutik Oleh Perawat Pada Pasien Di Ruang Rawat Inap Rumah Sakit Umum Daerah Raden Mattaher Jambi. Jurnal Akademika Baiturrahim. Vol 6. No. 2.

Elizabeth Hurlock, E.B. (2018). Psikologi Perkembangan Edisi 5. Jakarta: Penerbit Erlangga.

Fahrozi. (2017). Hubungan Kualitas Pelayanan Rumah Sakit dengan Kepuasan Pasien Pengguna BPJS Kesehatan Di Rumah Sakit Abdul Wahab Sjahranie Samarinda. Volume 5 No 1, 118-124.

Febriani, Eka. (2015). Gambaran Komunikasi Terapeutik Perawat dan Tingkat Kepuasan Pasien Di Ruang Rawat Inap RSUD Sultan Syahrief Mohammad Alkadrie Kota Pontianak. Volume 3 No 1

Hajriani. (2013). Hubungan Komunikasi Perawat dengan Tingkat Kepuasan Pasien yang Dirawat Di Ruang Perawatan bedah RSUD Haji Makassar

Handayani, I. T. (2018). Hubungan Komunikasi Terapeutik Perawat Pada 
Pelaksanaan Orientasi Pasien Baru dengan Kepuasan Pasien Di Ruang Rawat Inap Rumah Sakit Anton Soedjarwo Bhayangkara. Jurnal Keperawatan Untan.

Harahap, R. A. (2019). Buku Ajar Komunikasi Kesehatan. Jakarta: Prenadamedia Group

Haskas, Y. (2018). Hubungan Komunikasi Terapeutik dengan Kepuasan Pasien Di Ruang Rawat Inap Interna RSUD Kota Makassar. Jurnal Ilmiah Kesehatan Diagnosis Vol. 12, No. 5 eISSN : 23022531 .

Safitri, I. D. (2019) Gambaran Pelaksanaan Komunikasi Terapeutik Perawat di Ruang Rawat Inap Rumah Sakit Islam Sultan Agung Semarang: Universitas Diponegoro. Semarang

Kemendikbud, 2013. Rangkuman Statistik Dasar. Kementrian Pendidikan dan Kebudayaan Direktorat Jendral Pendidikan Dasar. Jakarta

Kusumo, M. P. (2017). Pengaruh Komunikasi Terapeutik Perawat Terhadap Kepuasan Pasien di Rawat Jalan RSUD Jogja. Yogyakarta: Jurnal Medicoeticolegal dan Manajemen Rumah Sakit, Vol. 6 No 1: $72-81$

Maulana, H. D. (2007). Promosi Kesehatan. Jakarta: Buku Kedokteran EGC.

Misi Siti, Z. S. (2016). Komunikasi Terapeutik Perawat Berhubungan Dengan Kepuasan Pasien. Yogyakarta: JOURNAL NERS AND MIDWIFERY INDONESIA, Vol. 4, No. 1, 30-34.

Muhith, A \& Siyoto, S. (2018). Aplikasi Komunikasi Terapeutik Nursing \& Helth. Yogyakarta: CV. ANDI OFFSET

Notoatmodjo, S. (2012). Metodologi Penelitian Kesehatan (Revisi Cet). Jakarta: Rineka Cip.

Nurhasanah, N. (2010). Ilmu Komunikasi dalam Konteks Keperawatan Untuk Mahasiswa Keperawatan. Jakarta : TIM.

Nursalam. (2016). Manajemen Keperawatan: Aplikasi Dalam Keperawatan Praktik
Keperawatan Professional. Jakarta: Salemba Medika.

Nursalam. (2017). Metode Penelitian Ilmu Keperawatan : Pendekatan Praktis. Jakarta: Salemba Medika.

Perry, A. G., \& Potter, P. A. (2010). Fundamental Keperawatan Edisi 7 Buku 1. Jakarta: Salemba Medika.

Pieter, H. Z. (2017). Dasar-Dasar Komunikasi bagi Perawat. Jakarta: Kencana.

Priyono. (2016). Metode Penelitian Kuantitatif. Sidoarjo: Zifatama Publishing.

Putra, A. (2013). Hubungan Komunikasi Terapeutik Perawat dengan Kepuasan Pasien Di Ruang Rawat Inap Rumah Sakit Umum Daerah Dr. Zainooel, Abidin. Jurnal Ilmu Keperawatan, Vol. 1, No. 1 ISSN: 2338-6371.

Rompas, V. L. (2017). Hubungan Antara Sikap dan Teknik Komunikasi Terapeutik Perawat dengan Kepuasan Pasien Rawat Inap Di Ruang Eunike RSU GMIM Kalooran Amurang. ejournal Keperawatan (e-Kp) Volume 5 Nomor 1.

Rusnoto, M. P. (2019). Hubungan Komunikasi dan Pelayanan Keperawatan dengan Tingkat Kepuasan Pasien. Jurnal Ilmu Keperawatan dan Kebidanan Vol. 10, No. 2 , 343-349.

Sajidin, M. (2009). Aplikasi Komunikasi Dalam Keperawatan. Jakarta: Salemba Medika

Simanjuntak, Y. T. (2019). Hubungan Pelaksanaan Komunikasi Terapeutik Perawat Dengan Kepuasan Pasien Kemoterapi One Day Care Rumah Sakit Murni Teguh Memorial Hospital Medan . Jurnal Online Keperawatan Indonesia Vol. 2 No. 1.

Sugiyono. (2017). Statistika Untuk Penelitian. Bandung: Alfabeta.

Sujarweni, W. (2014). Metodologi Penelitian Keperawatan. Yogyakarta: Penerbit Gava Media. 
Swarjana, I. K. (2015). Metodologi Penelitian Kesehatan (Edisi Revisi). Yogyakarta: CV. Andi Offset. From https://books.google.co.id/

Trandsyah, C.H.,\& Toni, J. (2018). Hubungan Penerapan Komunikasi Terapeutik Perawat Dengan Kepuasan Pasien. Padang: Jurnal Endurance STIKes YPAK 3 (1), 88-95.

Ulum, H. M. (2016). Buku Uji Validitas Dan Uji Reabilitas. Malang: StikesWCH Malang

Waluyo, Mardi. (2012). Stres Kerja dan Kepuasan Kerja Perawat Di Rumah Sakit Blitar. 
